\title{
MOVIES: THE AESTHETIC INTERDISCIPLINARY DEVICE BRIDGING THE DIVERSITY GAP
}

\author{
Lucia Y. Lu, Ph.D. \\ Valdosta State University, Valdosta, GA 31698, USA
}

\begin{abstract}
In the course of Exploring Social and Cultural Perspectives on Diversity, a course required for all students of education major, to enhance the teaching of the concepts of multicultural education, and the differentiation of culturally responsive strategies, the author as teacher educator and her students as teacher candidates supplement movies in this course conceptualizing pragmatics, semiotics and aesthetics into literacy education by inviting students of diversity to watch movies, talk about movies, write movies, and act movies. Pragmatics is the study of how language is used for communication in various social and cultural contexts; semiotics is the study of signs like languages, arts, music, dance, drama, films, and paralinguistics which includes the nonverbal communication signals, etc., that human created to mediate the world; and aesthetics is the artistic stance that learners take for responses to literacy experiences. The purposes of this study are multi-functional: to develop the multisensory acquisition of five literacy skills in thinking, listening, speaking, writing and reading in a pleasant and authentic discourse setting. Both students from diversity and mainstream cultures acquire natural language for social interaction. Based on research, most students from diversity need two years to develop the social language, while needing five years to obtain the academic language. The results from this research reveal that audio-visual approach in terms of movies fosters students' cultural awareness, expedites English as second language acquisition for social function toward academic success and globalization.
\end{abstract}

Keywords: pragmatics; semiotics; aesthetics; paralinguistics, social language; second language acquisition.

\section{Academic Discipline and Sub-Disciplines}

Applied Linguistics, Culture, English Language Education

\section{SUBJECT CLASSIFICATION}

English Language Education

\section{TYPE (METHOD/APPROACH)}

Case Study Research

\section{Council for Innovative Research}

Peer Review Research Publishing System

Journal: Journal of Advances in Linguistics

Vol 6, No 1.

editor@cirjal.com

www.cirjal.com, www.cirworld.com 


\section{INTRODUCTION}

The author explored the second language acquisition process of students from diversity, whose first language was not English at the urban school district in Georgia, US, for four semesters when she supervised teacher candidates' practicum from Pre-K to $4^{\text {th }}$ grade. The author and the teacher candidates employed "movies" in the after school program and found that movies expedited the ELLs (English language Learners) social language and benefited them for academic success too.

\section{The Limits in the Classroom}

Bardovi-Harlig (2011) assured that most ELLs have little opportunity to engage in appropriate linguistic activity outside classroom, which results in a growing awareness that simply exposing ELLs to grammatically correct rules is inadequate. The author observed that most K-4 students from diversity rarely asked questions or answered questions in the classroom, but kept smiling. Those students were very active when they played with their Spanish-speaking peers in the playground during recess or lunch time, while they had little interaction with their English-speaking peers. One new classroom teacher complained to me, "They have been in the U.S. for more than two years, but they did not pass CRCT's!" (The Criterion-Referenced Competency Test designed to measure students' performance in reading, English/language arts, mathematics, science and social studies in Georgia).

\section{The Limits of Teachers' Being Cultural Bounds}

The US Immigration Reform Bill (2013) proposed to issue W-Visas for nonimmigrant labors to solve the problem of labor shortage in the U.S, and the new bill issued up to 185,000 new working visas in the next four years. More people will immigrate into the U.S. bearing W-visas, and their children whose native language is not English will populate this country and legally enroll in the public schools. With the immigrant population grows, schools need to adapt culturally responsive strategies to help those students from diversity to learn English (Kozma, 2014), while most public school teachers are cultural-bound (Cushner, McClelland, \& Safford, 2012; Lu, 2014). Those teachers were not professionally trained with ESOL endorsement, were not passionate for their students from diversity, and are not able to work with their students and parents from diversity.

\section{The Limits of Communication: Sociopragmatic and Pragmalinguistic Failure}

In using languages for effective communication, learners have to figure out "when" it is appropriate to perform a particular language function and "how" to encode it (Ellis, 1995). Thomas (1983) noticed that learners frequently experience difficulties with both: "sociopragmatic failure", which occurs when learners produce socially inappropriate behavior, and "pragmalinguistic failure", which occurs when learners do not express themselves in a linguistically appropriate manner. This is the reason that "paralinguistics" (Magrath, 2015) or nonverbal communication signals (Cherry, 2014) obtained from observing real peoples' conversation in the authentic setting is necessary. Watching movies in this study is to fill up the gap, while there has been very little research on second language (L2) learning with movies (Gibson, 2014).

\section{Objectives}

Inspired by the Movie Script (Hoffner, 2003), the author and the teacher candidates supplemented movies in the after school program weekly by encouraging students to finish their daily assignments and to watch movies later. The movie activity engaged students and their parents from diversity, and developed the students' functional literacy (Ariza, 2009; Dolly, 1998) for social interaction towards academic success and globalization.

\section{PRAGMATIC, SEMIOTICS AND AESTHETICS}

\section{Pragmatics}

To Grice (1989), pragmatics is a branch of linguistics that deals with norms of conversation. Generally pragmatics was defined as the study of how language is used in communication in various social and cultural contexts (Ariza, 2009; Ellis, 1995; Reutzel \& Cooter, 2012). It covers a wide range of linguistic phenomena like deixis, conversational implicature, presupposition, illocutionary acts, conversational structures, and repair (Ellis, 1995). Pragmatics is particularly concerned with appropriateness, with regard to "what" is said in a particular context and "how" it is said.

\section{Semiotics}

Semiotics is the study of signs like languages, arts, music, dance, drama, films, cultures, etc. that humans created to mediate the world (Cunningham, 1992; Sebeok, 1978; 2001; Siegel, 2006). In this study, the movie is the target sign, with its audio-visual artistic device to demonstrate various paralinguistics (Magrath, 2015) or nonverbal communication signals (Cherry, 2014; Cushner, McClelland, Safford, 2012) such as kinesics, gestures, head movements, posture, eye contact, tone of voice, and facial expression that were infused in literacy education for appropriate and effective communication. For a good language art curriculum must be able to expand a learner's potential for understanding and communicating through various signs, not only languages (Burke \& Harste, 2008).

Movie is the all-inclusive audio-visal composite (Eisner, 1978; 2002; Goldberg, 2001; Piazza, 1999; Uhrmacher, \& Matthews, 2005) with languages, arts, music, dance, drama, cultures, and nonverbal communication signals, etc. which attract learners' attention more than books, and motivate their interest in using multisensory literacy skills in thinking, listening, speaking, reading, and writing, as well as nonverbal behaviors for more appropriate communication to achieve personal goals. 


\section{Aesthetics}

Aesthetics is the artistic stance that learners take to the responses to literary works (Cornett, 1999; Eisner, 1972; Goldberg, 2001; Piazza, 1999). In this study, movies are used beyond the scope of pragmatics, and are more attractive to students with the artistic/visual attributes. Debes (1969) defined "Visual Literacy" as a group of vision-competencies that a human being develops by seeing and simultaneously integrating other sensory experiences, and the development of these competencies is fundamental to normal human learning. To Dewey (1934), art is the visual form of experience that vivifies life. Langer (1957) extends it, and declares that works of art are projections or images of feelings, presenting feelings, and making it visible or audible or perceivable through the symbols.

\section{METHOD}

\section{Participants}

The author as the teacher educator, her students as teacher candidates, and students from PreK $-4^{\text {th }}$ grades in the after school program in the inner city in Georgia.

\section{Materials}

A good movie, like literature, that bears the moral themes such as the love of peace, justice, courage, honesty, kindness, righteousness, collaboration, and friendship (Norton, 2011). Since Disney movies comprise these themes, rich in action (Hoffner, 2003), and are employed in this study. The students' favorite movies are Finding Nemo, The Wizard of Oz, Little Mermaid, Lion King, Charlotte's Web, Pocahontas, etc. In this study, only The Wizard of Oz is discussed.

The Wizard of Oz, a musical fantasy, is one of the best-known films and part of American popular culture where Dorothy, a country girl, the Scarecrow, who lacks a brain, the Tin Man, who always got rusty, and the Cowardly Lion, who needs courage, representing people of diverse cultures, come together and collaborate to accomplish their life goals.

\section{Procedure}

The teacher candidates briefly introduced the story of the movie with literary elements like characterization, settings, plots, and the themes in the form of graphic organizer, and the key vocabulary words in the movies to enhance students' "comprehensive input" (Krashen, 1982) before they watched the movies.

Students were grouped by five or six mixed diversity and mainstream cultures. The whole class watched the movie for five minutes, and the $1^{\text {st }}$ group went outside of the classroom talking about the movie, picking up roles, writing the movie script (playwright) based on his/her role, sharing the draft of the movie script in the small group. Teacher candidates and the group members reviewed and modified the movie script for group rehearsal. The other groups kept watching the movie. Five minutes later, the $2^{\text {nd }}$ group went out to do the same activity until the last group completed the rehearsal. The whole class acted the movie.

Each group submitted the draft of the movie script to the teacher candidates who tutored the students in the after school program. Teacher candidates collected the drafts of the movie script, edited the draft, typed it, and highlighted the movie script with different colors, i.e. blue, red, green, purple, and yellow for students to take home, and memorize the script at home with the help of their parents for the week playing on Friday.

As usual, the teacher candidates introduced the beginning of the story when a powerful tornado came to a farm house where Dorothy and Toto her dog live, but they are unable to get into the storm cellar. Dorothy seeks safety in her bedroom. A wind-blown window sash hits her head and she falls unconscious on her bed. She wakes to find the house spinning in the air by the twister, and the storm howling outside the window. Later her house landed on the Munchkinland in the land of $\mathrm{Oz}$, and accidently killed the wicket witch. All the Munchkins welcomed Dorothy and Toto (Wikipedia). The students started to watch the movie from this point.

\section{RESULTS}

The following draft of movie script on "The Wizard of $O z$ " were written by three groups of students with the teacher candidates who tutored the students in the after school program. 


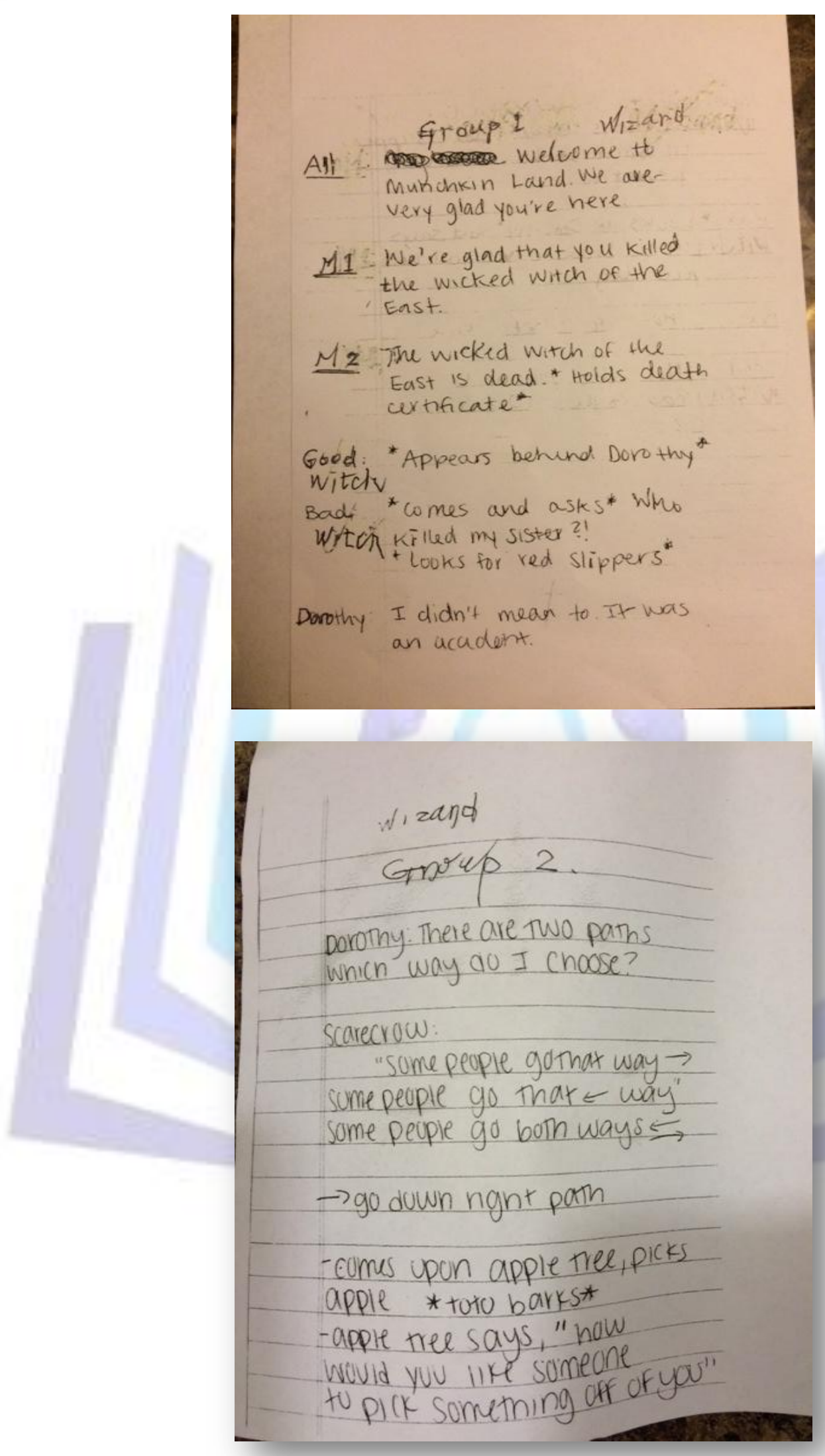




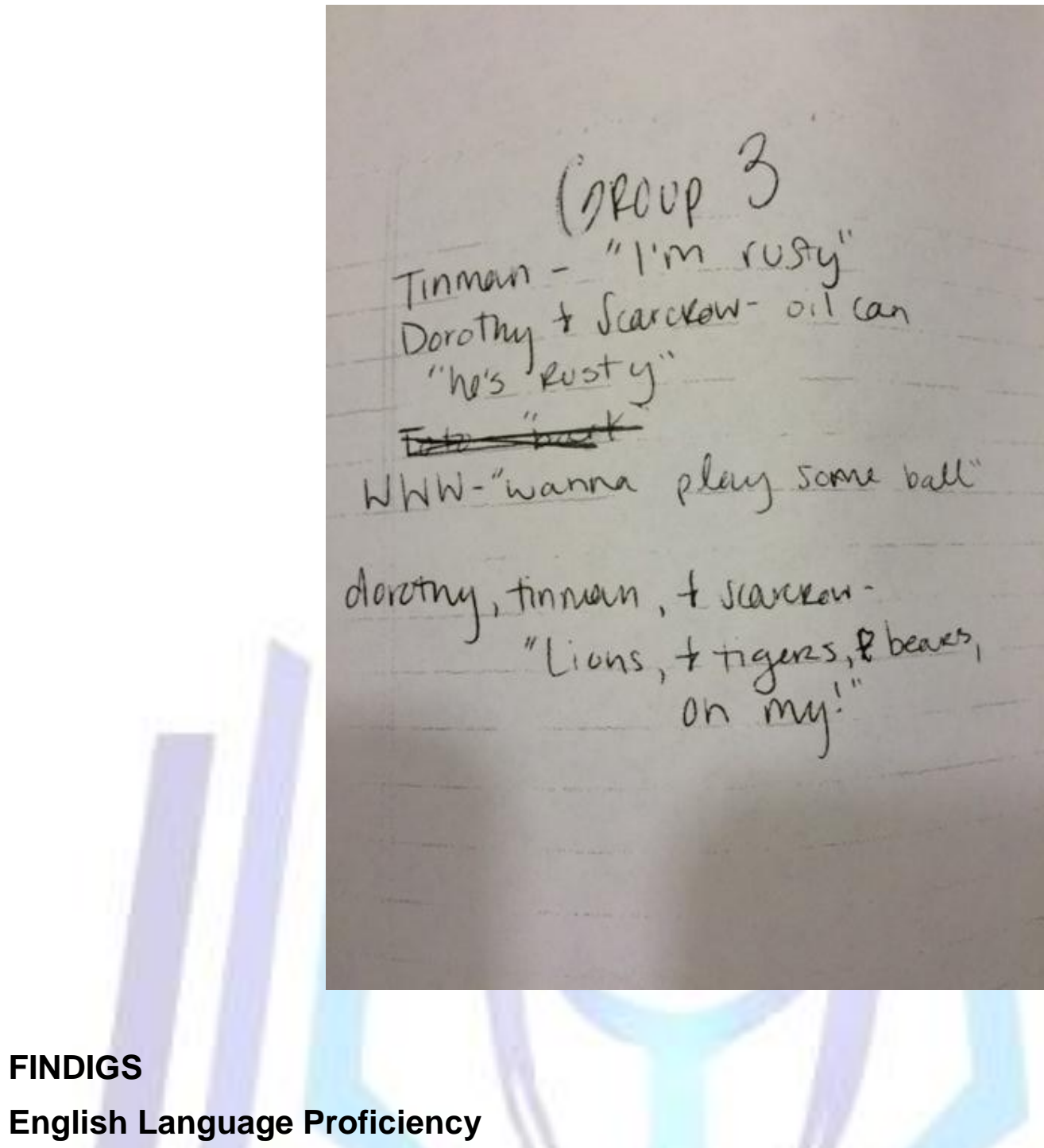

Movies invited multisensory development through the stimuli of audio-visual device for listening comprehension, speaking fluency, writing skills (movie script), reading competency, critical thinking, and imagination. For example, every student, either from diversity or the mainstream cultures, was able to use invented spellings (Laminack \& Wood, 2006) as well as conventional spellings to write at least two complete sentences as movie scripts to express what he/she watched of the movie for five minutes. The author noticed that students in each group learned the social skills for respectful manner. They listened to each other, they talked, they discussed, they negotiated, and they reconciled in English. They read their peer's script, and help to edit the scripts. The five literacy skills in thinking, listening, speaking, reading and writing were practiced in each group. During rehearsal, each student was able to include the nonverbal communicational signals in the acting.

\section{Movie as One Form of Visual Literacy}

Based on Gardner (1983), people were born with different intelligences and have different learning styles. But all normal humans learning better through visual or audio device.

Research suggests that people learn abstract, new, and novel concepts more easily when they are presented in both verbal and visual form (Salomon, 1979). Other empirical research shows that visual media make concepts more accessible to a person than text media and help with later recall (Cowen, 1984)

\section{Pragmatic Competency: Teaching Natural Conversation}

In addition to the instruction of essential linguistics (Freeman \& Freeman, 2014) like reading strategies, ESL, spelling, phonics, and grammar, the teacher educator implemented activities for Pragmatics: Teaching natural conversation (Houck, \& Tatsuki, 2011) in this course, so that teacher candidates will learn how to teach their students of diversity the following interactional activities in authentic language patterns, e.g. expressing gratitude (Bardovi-Harlig \& Nickels, 2011), saying apologies (Lieske, 2011), paying compliments (Carduner, 2011), taking turns \& talking naturally (Carroll, 2011), and performing pragmatic competency in telephone conversation (Wong, 2011) by role play and small group activity. Through this kind of authentic discourse, the ELLs develop functional literacy (Dolly, 1998) for social success. 


\section{Communicative Competence}

The ability to use language is a contextually appropriate fashion, and pragmatic competence is a fundamental aspect of a more general communicative competence including the effectiveness of communication for the purposes of confirming, commending, convincing, and persuading. To achieve the communicative competence, what the learners need is beyond the correct instruction of phonics (sound system), syntax (grammar), and semantics (meaning). They need to understand and communicate with the various types of nonverbal communication signals: kinestics, gestures (emblems, illustrations), head movement, posture, eye contact, facial expression, and intonation in an appropriate manner (Cherry, 2014; Magrath, 2015).

\section{Sociolinguistic Competence}

Learners are expected to be knowledgeable about sociocultural rules of using languages. It is concerned with the learners' ability to handle settings, topics and communicative functions in different sociolinguistic contexts. In addition, it deals with the use of appropriate grammatical forms for different communicative functions in different sociolinguistic contexts, and social skills for collaboration through speaking, talking, discussion, negotiation and organization for the building of leadership. The author always encouraged the teacher candidates to assign students in the small groups took turns to be the leading role as movie director. Students from diversity as well as the mainstream, boys, girls, struggling learners, advanced learners, that means, everyone had the opportunity to take the leading role.

\section{Discourse Competence}

This is related to the learners' mastery of understanding and producing texts in the modes of thinking, listening, speaking, reading and writing. It deals with cohesion and coherence in different types of texts.

\section{Cultural Awareness}

Magrath (2015) declared that the study of a second language is the study of another culture. Language is both a product and a shaper of culture (Cushner, McClelland, \& Safford, 2012). Language and culture are intertwined. Through the study of other languages, students gain a knowledge and understanding of the cultures that use the language. Students learning English, or any other language, also learn the target culture. Movies in this study convey the knowledge of culture, and strategies for language acquisition as well. To help students from diversity to transit to the dominate culture and accommodate to American culture is as important as English language acquisition.

\section{DISCUSSION}

\section{Social Media Enhance Interdisciplinary Teaching and Learning}

Gibson (2014) declared that there has been very little research on second language learning with movies, and there does not appear to be any data on the amount of time that $L 2$ learners watch movies.

Crumpler (2014) recommended that social media can truly spark curiosity and engage the interests of youth today. Educators must reach them through what they find interesting. Social media is a powerful tool that classroom teachers can use to deeply access the learning potential of the young generation. Based on her research, schools and educators need to implement effective strategies for dropout prevention in all education levels and environments.

\section{Movies for Interdisciplinary Teaching and Learning}

Inspired by www.teachwithmovies.org, the author and the teacher candidates surveyed the movies in forms of DVD, YouTube, Films on Demand, and wrote the following lesson plans for their students from Prek - 12 grades with CCGPS the Common Core in Georgia Performance Standards, and the assessment by questions based on Bloom's Taxonomy.

\begin{tabular}{|c|c|c|}
\hline Movies & CCGPS & Objectives \\
\hline $\begin{array}{c}\text { "Cyber Chase" PBS } \\
\text { movie clip }\end{array}$ & $\begin{array}{c}\text { Math: } \\
\text { 2.MCC2.MD.8 }\end{array}$ & $\begin{array}{c}\text { Solve word problems involving dollar bills, quarters, dimes, nickels, } \\
\text { and pennies, using \$ and \$ symbols appropriately. }\end{array}$ \\
\hline $\begin{array}{c}\text { The Cat in the Hat } \\
\text { Arts: 3.RF3 }\end{array}$ & $\begin{array}{c}\text { English Language } \\
\text { Know and apply grade-level phonics and word analysis skills in } \\
\text { decoding words. }\end{array}$ \\
\hline $\begin{array}{c}\text { YouTube Pearl } \\
\text { Harbor }\end{array}$ & $\begin{array}{c}\text { Social Studies, US } \\
\text { History: SSUSH19 } \\
\text { b }\end{array}$ & $\begin{array}{c}\text { Explain the Japanese attack on Pearl Harbor and the internment of } \\
\text { Japanese- Americans, German-Americans, and Italian-Americans. }\end{array}$ \\
\hline $\begin{array}{c}\text { DVD American } \\
\text { Sniper }\end{array}$ & $\begin{array}{c}\text { Social Studies, US } \\
\text { History: SSUSH25 } \\
\text { g }\end{array}$ & $\begin{array}{c}\text { Analyze the response of President George W. Bush to the attacks of } \\
\text { September 11, 2001, on the United States, the war against terrorism, } \\
\text { and the subsequent American intervention in Afghanistan and Iraq. }\end{array}$ \\
\hline DVD The Blind Side & $\begin{array}{c}\text { Social } \\
\text { Psychology: }\end{array}$ & $\begin{array}{c}\text { The student will analyze the impact of the social environment on } \\
\text { behaviors and attitudes. }\end{array}$ \\
\hline
\end{tabular}




\begin{tabular}{|c|c|c|}
\hline $\begin{array}{c}\text { The Magic School } \\
\text { Bus: Water Cycle }\end{array}$ & $\begin{array}{c}\text { Science, Earth } \\
\text { Science: S4E3 }\end{array}$ & $\begin{array}{c}\text { Students will differentiate between the states of water and how they } \\
\text { relate to the water cycle and weather. }\end{array}$ \\
\hline DVD The Lorax & $\begin{array}{c}\text { Science, Life } \\
\text { Science: S3L2 }\end{array}$ & $\begin{array}{c}\text { Students will recognize the effects of pollution and humans on the } \\
\text { environment. }\end{array}$ \\
\hline $\begin{array}{c}\text { DVD The } \\
\text { Dodgeballs }\end{array}$ & PE 8.2 & $\begin{array}{c}\text { Demonstrates understanding of movement concepts, principles, } \\
\text { strategies, and tactics as they apply to the learning and performance } \\
\text { of physical activities. }\end{array}$ \\
\hline DVD & Music 2 B & $\begin{array}{c}\text { Performing on instruments, alone and with others a varied repertoire } \\
\text { of music B. Perform a steady... }\end{array}$ \\
\hline
\end{tabular}

\section{Multicultural Movies Make Teacher Candidates the Cultural Mediator}

The following movies are supplemented in this course for developing teacher candidate's cultural awareness for cultural competent in their future classrooms.

The Education of Little Tree (Theme: American cultural assimilation)

The Karate Kid (Theme: school bully faced by the children immigrants)

The Piano (Theme: the aesthetic expression of American Sign Language)

The Shunning (Theme: the effect of social institutions over the Amish people)

The Freedom Writers (Theme: educating the Inner city children)

\section{CONCLUSION}

The study in this research reveals that movies provide valuable resources in second language classrooms and fit Krashen's second language acquisition hypotheses (1982): acquisition rather than learning, natural approach, comprehensive input, free filter environment, self-monitor opportunity, and motivate ELLs' interest in learning. The benefits of using movies in second language classroom are to bridge the diversity gap (Dallabrida, 2015), especially the audiovisual artistic effects, and the nonverbal communication manners to the second language learners for acquisition of language proficiency and social/cultural competency.

\section{REFERENCES}

[1] Ariza, E. N. (2009). Not for ESOL teachers: What every classroom teacher needs to know about the linguistically, culturally, and ethnically diverse students ( $2^{\text {nd }}$ ed.). New York: Pearson Education, Inc.

[2] Bardovi-Harlig, K. (2011). Assessing familiarity with pragmatic formula: Planning oral/aural assessment. In N. R. Houck, \& D. H. Tatsuki (Eds.). Pragmatics: Teaching natural conversation (pp. 2-22).

Alexandria, VA: TESOL Inc. Retrieved from blog.tesol.org/8-current-trends-in-teaching-and-learning-eflesl/

[3] Burke, C., \& Harste, J. (2008). Profiles and perspectives. Language Arts, 86(2). 120-126.

[4] Carduner, J. (2011). Have you paid someone a compliment today? In N. R. Houck, \& D. H. Tatsuki (Eds.).

Pragmatics: Teaching natural conversation (pp. 61-78). Alexandria, VA: TESOL Inc.

[5] Carroll, D (2011). Taking turns and talking naturally: Teaching conversational turn-taking. In N. R. Houck, \& D. H.

Tatsuki (Eds.). Pragmatics: Teaching natural conversation (pp. 91-104). Alexandria, VA: TESOL, Inc.

[6] CCGPS: Common Core in Georgia Performance Standards

[7] Cherry, K. (2014). Top 10 nonverbal communication tips. Psychology about.com

[8] Cornett, C. E. (1999). The arts as meaning makers: Integrating literature and the arts throughout the curriculum.

Columbus, $\mathrm{OH}$ : Merrill, an imprint of Prentice Hall.

[9] Cunningham, D. J. (1992). Beyond educational psychology: Steps toward an educational semiotic. Educational Psychology Review, 4, 165-194.

[10] Cushner, K., McClelland, A., \& Safford, P. (2012). Human diversity in education: An intercultural approach (7ed.). New York:McGraw Hill. 
[11] Dallabrida, E. S. (2015). Bridging the gap: Stories of everyday educators and their extraordinary acts to meet students' basic needs. Reading Today, Volume 32(6). 10-13.

[12] Debes, J. (1969).What is visual literacy? International Visual Literacy. Retrieved from http://en.wikipedia.org/wiki/Visual literacy 8, April 2010.

[13] Dolly, M. R. (1998). Integrating ESL reading and writing through authentic discourse. In M. F. Opitz (Ed.). Literacy instruction for culturally and linguistically diverse students (pp.161-167). Newark, DE: International Reading Association.

[14] Eisner, E. W. (Ed.) (1978). Reading, the arts, and the creation of meaning. Reston, VA: National Art Education Association.

[15] Eisner, E. W. (2002). The arts and the creation of mind. New Haven \& London: Yale University Press.

[16] Ellis, R. (1995). The study of second language acquisition. Great Britain: Oxford University Press.

[17] Freeman, D. E., \& Freeman, Y. S. (2014) (2 ${ }^{\text {nd }}$ ed.). Essential linguistics: What you need to know to teach ESL, reading, spelling, grammar. Portsmouth, $\mathrm{NH}$ : Heinemann.

[18] Gibson, R. (2014). The second language learning with movies. Retrieved from Ezine Mark.com

[19] Goldberg, M. 2001). Arts and learning: An integrated approach to teaching and learning in multicultural and multilingual settings. New York: Longman.

[20] Gormly, K. B. (2013). Movies enhance language-learning program, Retrieved from TriLIVE (December 6, 2013).

[21] Grice, H. P. (1989). Studies in the way of words. Cambridge, MA: Harvard University Press.

[22] Griffin, L. (2015). Using video in the classroom. Retrieved from http://www.libraryvideo.com/articles/article13.asp [23] Hamilton, E. (2010). Motivating students to develop their English literacy skills through science. In Nordmeyer \& S. Barduhn (Eds.) Integrating language and content (pp. 231-239). Alexandria, VA: TESOL, Inc. [24] Hoffner, H. (2003). Movie script. The Reading Teacher, 57(1). 78-80.

[25] Houck, N. R., \& Tatsuki, D. H. (Eds.) (2011). Pragmatics: Teaching natural conversation. Alexandria, VA: TESOL,Inc.

[26] Hunt, K., \& Walsleben,, L. (210). What counts as good math instruction for English language learners. In . In J. Nordmeyer \& S. Barduhn (Eds.) Integrating language and content (pp. 209-218). Alexandria, VA: TESOL Inc. [27] Kozma, C. (2014). As immigrant population grows, schools adapt to help kids learn English. Retrieved from ckozma@s-t.com

[28] https://serc.carleton.edu/sp/library/media/why.html

[29] https://serc.carleton.edu/sp/library/media/how.html

[30] Krashen, S. (1982). Principles and practice in se language acquisition. New York: Pergamon Press.

[31] Laminack, L. L., \& Wood, K. (2006). Spelling in use. Urbana, IL: National Council of Teachers of English.

[32] Langer, S. K. (1957). Problems of arts. New York: Charles Scribner's Sons.

[33] Lieske, C. (2011). Oh, I'm so sorry! Are you all right? Teaching apology. In N. R. Houck, \& D. H. Tatsuki (Eds). Pragmatics: Teaching natural conversation (pp. 41-60). Alexandria, VA: TESOL, Inc.

[34] Lu, Y. L. (2014). Literacy, culture, content: The semiotic triad breaks cultural bounds for diversity and equity. Journal of Foreign Languages, Cultures and Civilizations. Vol 2(1).1-19.

[35] Magraph, D. (2015) Multibrief: Paralinguistic concern for ESL instructors. Retrieved from http://eclusive.multibriefs: Paralinguistic concerns for ESL instructors.

[36] Magrath, D. (2015). The importance of culture in ESL teaching. Retrieved from http://exclusive.multibriefs.com/content/he-importance-of-culture-in-esl teaching/education.

[37] Nordmeyer, J. (2010). At the intersection of language and contents. In J. Nordmeyer \& S. Barduhn (Eds.) 
Integrating language and content (pp. 1-13). Alexandria, VA: TESOL, Inc.

[38] Piazza, C. L. (1999). Multiple forms of literacy: Teaching literacy and the arts. Upper Saddle River, NJ: Merrill, an Imprint of Prentice Hall.

[39] Sebeok, T. A. (2001). Signs: An introduction to semiotics. Toronto, CA: University of Toronto Press.

[40] Sebeok, T. A. (1978). Sight, sound, and sense. Bloomington, IN: Indiana University Press.

[41] Sysoyev, P. V., \& Funderburg-Foreman, S. R. (2010). Developing language skills while studying cultural identity. In J. Nordmeyer \& S. Barduhn (Eds). Integrating language and content (pp. 193-206). Alexandria, VA:

TESOL, Inc.

[42] Siegel, M. (2006). Rereading the signs: Multimodal transformations in the field of literacy education. Language Arts, 84(1), 65-77.

[43] Teach with Movies: Lesson plans based on movies \& film clips

[44] Thomas, J. (1983). Cross-cultural pragmatics. Applied Linguistics 4: 91-112.

[45] Uhrmacher, P. B., \& Matthews, J. (2005). Intricate Palette: Working the ideas of Elliot Eisner. Columbus, $\mathrm{OH}$ : Pearson Merrill Prentice Hall.

[46] Wong, J. (2011). Pragmatic competency in telephone conversation. In N. R. Houck, \& D. H. Tatsuki, (Eds.). Pragmatics: Teaching natural conversation (pp. 119-152). Alexandria, VA. TESOL, Inc.

\section{Author's Biography}

Lucia Y. Lu, Ph.D. is an associate professor at Valdosta State University, Georgia, USA. She graduated from National Taiwan University with a bachelor degree in Foreign Languages \& Literatures, and obtained her Ph.D. in Language Education - Reading from Indiana University-Bloomington. She conceptualizes semiotics and pragmatics into her teaching of reading and literacy at graduate and undergraduate levels. 